\title{
International Federation for Documentation
}

\section{Conference at Oxford and London}

\begin{abstract}
"Documenter e'est réunir, classer et distribuer des documents de tout genre dans tous les domaines de l'activité humaine."
\end{abstract}

$7 \mathrm{H}$ fourteenth International Conference for Documentation, which has just been held at Lady Margaret Hall, Oxford, and the Science Museum, London, under the patronage of the British Government and the presidency of Sir William Bragg, has provided a demonstration of the increasing realization of the fundamental importance of documentation in intellectual and material progress. The three hundred and fifty members of the Conference included delegates of thirty Governments and a hundred and fifty leading scientific and learned societies, research institutions, and international associations. The growing interest in the work of the Federation was reflected in the aggregate of 106 papers communicated, an increase of 150 per cent on the number presented to the Jubilee Conference of the Federation at Copenhagen three years ago. Above all, the spirit of international collaboration, which inspires the Federation, made itself felt, not only in the study of the means of co-operation in the task of making more fully available the records of human progress, but also in a remarkable feeling of international friendship and good will, which has pervaded the atmosphere of the Conference throughout its proceedings.

The Conference has demonstrated, in no uncertain manner, the intense desire of thinking men and women all over the world to collaborate in the solution of international problems, including among them the co-ordination of documentary work, as one of the most powerful means of promoting the happiness and material progress of mankind.

As Lord Stanhope remarked, in proposing the toast of the International Federation for Documentation at the Government banquet, "that is not knowledge, which we do not know where to find". Buried in books, journals, monographs, reports, patent specifications and archives, to which continual additions are being made, lie masses of invaluable data and records of advances in every field of knowledge. These facts lie hidden and inaccessible for want of a comprehensive index whereby to make them available as the basis of further progress. In the absence of such an index, incalculable time, money and labour are being wasted every day in the repetition of investigations already completed. To prevent this unnecessary delay, effort and expense is the object of the International Federation for Documentation, which seeks to unite all those engaged in the collection, classification and distribution of information, as well as everyone seriously concerned with the progress of knowledge, in the study and solution of this economic problem. The importance of such work was pointed out by Sir William Bragg in his presidential address on "The Historical Papers of the Royal Institution".

The subjects discussed in papers by leading authorities from all countries might be said to cover almost the whole field of documentation. The sessions were devoted to symposia on such subjects as : the making of abstracts from periodical literature; applications of indexing systems; the practical application and use of bibliographies; the teaching of documentation; theories of cataloguing and classification; the organization of information services; and tools for library co-operation.

Two sessions, allotted to the discussion of photographic and other technical methods in their application to bibliographical problems, and apparatus for photographic reproduction of documents, were par. ticularly valuable, as providing the most fully representative descriptions of the latest apparatus and authoritative opinion of all countries. The exhibition arranged in the Science Museum, through the kindness of Colonel E. E. B. Mackintosh, illustrating the most up-to-date apparatus, material and methods available for the purpose, is now open to the public and should certainly be visited.

In accordance with a suggestion made at the World Congress on Documentation, held in Paris last year, that, in the past, the Federation had concentrated too exclusively on the scientific field, a special attempt was made at this Conference to include authoritative reports on the present state of bibliographical work in such fields of learning as archæology, archive work, economics, finance, history, law and painting. This led to one of the most important sessions of the Conference. Another session was devoted to a paper by Prof. A. F. C. Pollard, president of the British National Section of the Federation, on the mobilization of knowledge and the "Permanent World Encyclopædia" of Mr. H. G. Wells. Assuming that the need for such an encycl pædia has been demonstrated conclusively, Prof. Pollard gave an able survey of the reasons that have prevented the realization of this undertaking in the past, and indicated the mechanism by which these difficulties may surely and efficiently be overcome. This is a paper the value of which is likely to be more greatly appreciated with lapse of time. Mr. H. G. Wells, who was present at this sitting, made a stimulating contribution to the discussion.

The address of the president of the International Federation, Dr. Alingh Prins, on problems of international documentation, was given during the weekend, when the members of the Association of Special Libraries and Information Bureaux also were present for their annual conference and the full attendance was reached. As a clear, comprehensive and con. cise synopsis of the problems involved, and the simple and completely effective methods available for their solution, this paper was certainly one of the most important contributions to the Conference. Also during the joint sessions with ASLIB, Mr. E. Lancaster Jones read a useful paper on the evaluation of scientific and technical periodicals. This included suggestions of methods utilizable by libraries in choosing periodicals to take.

From the above, it will be seen that the Transactions of the fourteenth Conference of the Inter- 
national Federation for Documentation contain perhaps the most comprehensive collection of original authoritative papers within its field, and should be studied by everyone who has at heart the mobilization of recorded information. The first issue has already been sold out. But, by the time these notes are in print, a new issue will be available at the moderate price of $£ 1$ net for the three volumes. These will be obtainable directly from the International Federation for Documentation, Willem Witzenplein 6, The Hague, or from its British National Section, British Society for International Bibliography, at the Science Library, Science Museum, South Kensington, S.W.7.

Those who are seriously interested in the task of making recorded information more fully available should put themselves in touch with Miss M. Gosset, the honorary secretary of the British Section at the above address.
Sir William Bragg's presidential address, as well as Dr. Alingh Prins' lecture as president of the Federation, together with the discussions of the papers, will be printed in the Communicationes published quarterly by the Federation.

Space will not permit to describe the Government banquet in the beautiful Hall of Christchurch, presided over by Lord Stanhope, the reception by the Vice-Chancellor in the Ashmolean Museum, the hospitality of the Mayor in the Town Hall, the garden party given by Dr. and Mrs. Priestley at their beautiful manor house at March Baldon, the interesting visit to Messrs. Morris Motors Ltd., the tea provided by Messrs. Kodak Ltd., and the various other visits and excursions, which did so much to create the prevailing atmosphere of friendship and provided those opportunities of social contact that constituted such a valuable part of the proceedings of the Conference.
S. C. BRAdFord.

\section{Association of Special Libraries and Information Bureaux}

\section{Annual Conference}

\begin{abstract}
THE fifteenth annual conference of the Association of Special Libraries and Information Bureaux, held at Lady Margaret Hall, Oxford, on September 23-26, was somewhat overshadowed by the anxiety of the political situation, and also by the Conference of the International Federation for Documentation, which held its fourteenth annual conference simultaneously. If the joint sessions with the latter Federation unfortunately suffered from the depressing effect of an excessive number of papers which characterized the sessions of the International Federation, the remaining meetings at the ASLIB Conference had their characteristic spontaneity, and the discussion on the work of the Association at the annual meeting in particular indicated a lively interest on the part of members in its continued progress.
\end{abstract}

The president-elect, Sir William Beveridge, was unfortunately prevented by illness from giving his address on "The Use of Books in Social Science". Mr. E. W. Wignall's paper on "Museums and Research : Some Facilities in London", gave an indication of the extent to which museum officers carry out research, not only for their own departments but also for Government departments, universities and scientific institutions of different kinds all over the world. Facilities for workers not on the staff of a museum are often limited by the space available or the demands made on the time of the museum staff, and Mr. Wignall urged that in any new museum it is of the utmost importance that adequate study rooms should be provided. He also stressed the question of acknowledgment, very considerable help being sometimes given to a student which receives no acknowledgment in his subsequent papers. A brief subject list of museums in London was included in the paper.

At the annual general meeting of the Association, the honorary treasurer, Mr. A. F. Ridley, submitted accounts showing a slight balance of income over expenditure as compared with the deficit of the previous year. Although the membership of the Association has also increased from 308 to 325, the report of the Council once more emphasizes the necessity for a much larger membership if the Association is to fulfil the functions which belong to it. The report also refers to the increased circulation of the ASLIB Book-List and to the issue in May of a second edition of the "Select List of Standard British Scientific and Technical Books". Increasing use is being made of the inquiry bureau, and the panel of expert translators has been reorganized, a new register having been established under new regulations. Eighty-six members have now been enrolled under the modified scheme.

In the absence of Sir William Beveridge, Mr. B. M. Headicar presided over the evening session on September 24, when Mr. Frederick Brown, lecturer in statistics at the London School of Economics, read a paper on "The Compilation of Statistics by Trade Associations", in which his felicity and liveliness of exposition drew the warm appreciation of a large audience. Mr. Brown referred to the difficulty of generalizing about the statistics compiled or issued by trade associations owing to the wide variations in practice both in compilation and in objective or use. Terminology is also important, as frequently trade statistics cannot be interpreted without knowledge of special terms used, or of the way in which they are compiled. Among the services which trade associations can render to their members in this way is the reproduction of market prices of special interest to them in the calculation of special index numbers.

While most trade associations base their statistical work on data collected and compiled outside, some few associations are breaking fresh ground, and $\mathrm{Mr}$. Brown emphasized the opportunities which await trade associations in the field of statistical research, in such matters as the compilation of figures of consumption and production by members, stocks and plant capacity and operating or production costs. In this connexion, Mr. Brown pointed out that if such work is to have any value, membership of the 